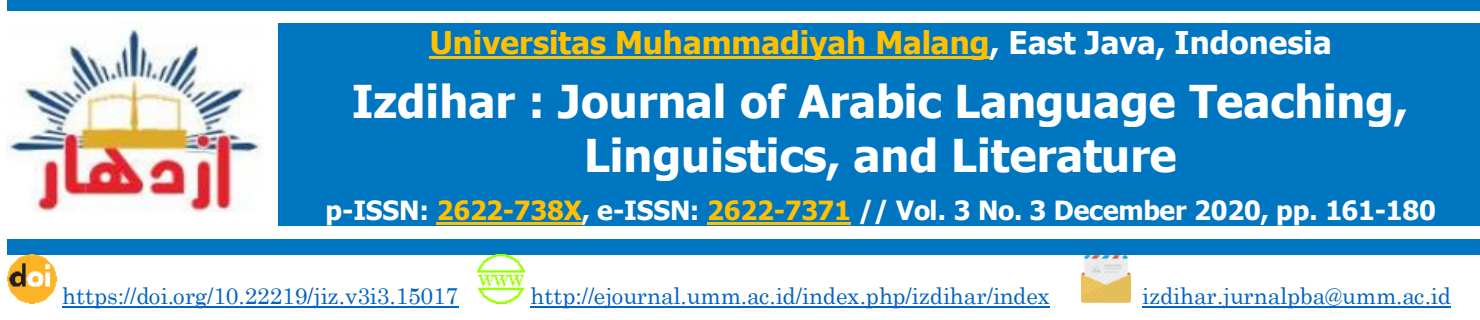

\title{
Developing Arabic Language Instructional Content in Canvas LMS for the Era and Post Covid-19 Pandemic
}

\section{Moh. Fery Fauzia, 1 , Murdiono Murdiono ${ }^{b, 2}$, Irma Anindiatic, 3 , Auqi Lu'lu In Nada ${ }^{d, 4}$, Rifqi Rohmanul Khakim ${ }^{\text {, }}$, Lailatul Mauludiyah ${ }^{\mathrm{f}, 6}$, $\mathrm{I}^{\prime}$ anatut Thoifah ${ }^{\mathrm{g}, 7}$ \\ a, $d$, eUniversitas Negeri Malang, Indonesia \\ $a, b, f, g$ Universitas Muhammadiyah Malang, Indonesia \\ cUIN Maulana Malik Ibrahim Malang, Indonesia}

1mohferyfauzi.fs@um.ac.id, 2murdiono@umm.ac.id, 3irmaanindiati@gmail.com,

4auqiluluinnada@gmail.com, 5 rifairohman08@gmail.com, ${ }^{6}$ elimauludiyah@umm.ac.id, ${ }^{7}$ thoifah@umm.ac.id*

\section{ARTICLE INFO}

\section{Article History:}

Received: 01/12/2020

Revised: $30 / 12 / 2020$

Accepted: $31 / 12 / 2020$

Published: $31 / 12 / 2020$

\section{*Corresponding}

\section{Author:}

Name: I'anatut

Thoifah

Email:

thoifah@umm.ac.id

\section{ABSTRACT}

Online and offline learning practices must not ignore technology, instructional content, pedagogy, psychology, and other aspects of teaching and learning process. Instructional content needs more attention during and after Covid-19 pandemic because it must match the characteristics of students. Therefore, this problem has led to the development of $\mathrm{mE}-$ Book for Arabic learning in Canvas Learning Management System (LMS). This research aimed to investigate the effectiveness of $m E-B o o k$ as instructional content for Arabic language learning in Canvas LMS and the extent of $\mathrm{mE}$-Book acceptance by students in the framework of the Technology Acceptance Model (TAM) 3. This research used a nonrandomized control group pretest-posttest design by comparing two groups with and without mE-Book and the interview to know the students' point of view about mE-Book. The results showed that mE-Book was effective as instructional content for Arabic language learning in Canvas LMS with large effect based on effect size criteria. Students' perspectives showed that the use of mEBook as instructional content for Arabic language learning in Canvas LMS is interesting for online and offline learning. In conclusion, students could accept mE-Book in learning activity in Canvas LMS because it eased students in Arabic language learning.

Copyright (C) 2020, Fauzi et al This is an open access article under the CC-BY-SA license

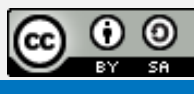

Canvas; Covid-19; ICT; Instructional Content; LMS; mE-Book

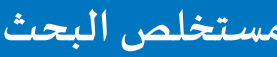

يجب ألا تتجاهل ممارسات التعلم عبر الإنترنت ودونها الجوانب التكنولوجية والمحتويات التعليمية والتربوية والنفسية والجوانب الأخرى لعملية

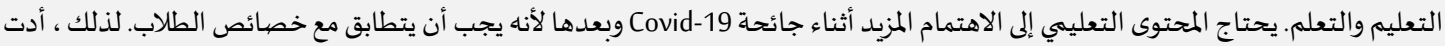

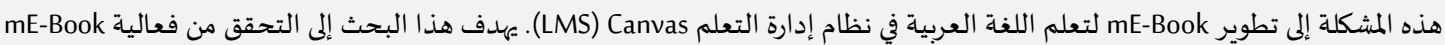

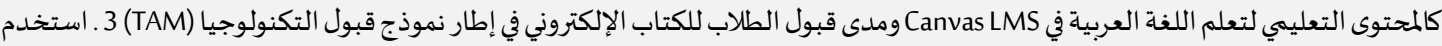

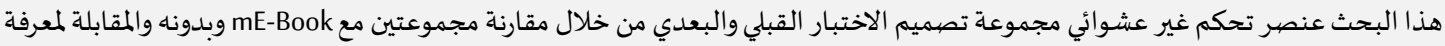

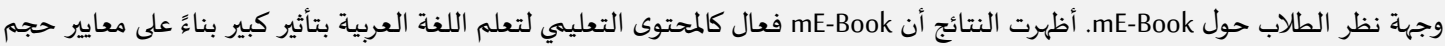

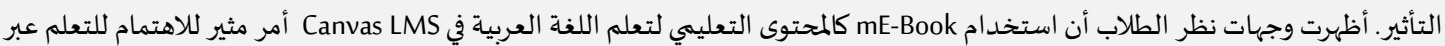
الإنترنت وفي وضع عدم الاتصال. في الختام ، يمكن للطلاب قبول mE-Book في نشاط التعلم في Canvas LMS لأنه يسهل الطلاب تعلم اللغة العربية. 


\section{INTRODUCTION}

The flow of globalization and the very rapid development of information and communication technology (ICT) in the last decade has affected every aspect of human life (Fauzi, Fatoni, \& Anindiati, 2020, p. 173). Education is one aspect affected by the development of ICT especially Arabic language learning. There is no doubt that the development of ICT, with its various aspects of modernity, has contributed greatly to the development of education in this modern era. The challenges of the world and the rapid changes in all aspects of social, economic, and cultural life today require educational institutions to answer the challenges of this world by conducting modern and future-oriented learning. Rusman, Deni Kurniawan, and Riyana (2013, p. 1 ) said that global demands require the world of education to always adapt technological developments in efforts to improve the quality of education.

Improving the quality of education does not just happen itself. Improving the quality of education is directly proportional to the increase in skills possessed by teachers and graduates. One of the efforts to improve the quality of education is to increase the professionalism of teachers and graduates. Organizing an educational program that follows technological developments is one way of increasing the professionalism of the teachers and the graduates. The application of ICT to improve the quality of learning has been researched by researchers. Gale (Chang, 2007) said that that students are more motivated and like computer-based learning activities. Students become independent, active, and can explore in a short time when learning using multimedia programs.

Arabic Department in Universitas Muhammadiyah Malang is committed to provide ICT-based education, teaching, and learning processes. The ICT-based Arabic language teaching and learning process cannot run well without supporting infrastructure and adequate human resource capabilities because Fitriyah and Fauzi (2020, p. 18) said that mastering Arabic language mean know all things that are at the level of language. To realize it, there are several standards that must be held by all lecturers because education is delivery process of science, information, expertise, and values (Furqon \& Fauzi, 2019, p. 68). Rusman et al., (2013) said that there are three standards that lecturers must have: (a) a general understanding and technological ability, (b) capability in using technology to improve skills in professional and personal life, (c) capability to integrate technology into the curriculum effectively. In order to have these abilities according to the three standards for lecturers, it is important for education providers to prepare educational programs in accordance with these demands.

A challenging problem which arises in this domain is preparing Arabic language instructional content in the era and post Covid-19. This problem has 
received substantial interest. This leads to myriad problems in online and offline learning of Arabic language in higher education. The problems are very complex such as disadvantages regarding technology, communication, finances (De Paepe, Zhu, \& Depryck, 2018, p. 20), the lack of training sessions that aimed to increase students' technology acceptance (Zhang \& Zou, 2020, p. 26), humility (Foster, 2019, p. 1), pedagogical concerns (Brudermann, 2015, p. 267), and learning design to understand student online engagement (Rienties, Lewis, McFarlane, Nguyen, \& Toetenel, 2018, p. 1).

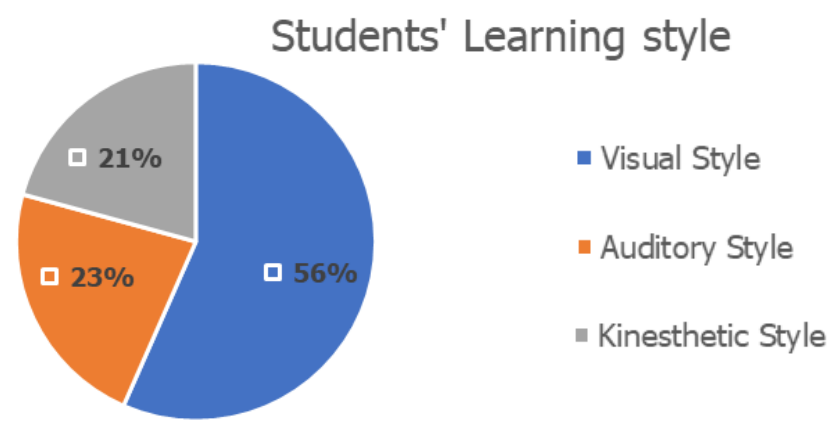

Figure 1. Students' Learning Style

A well-known problem with teaching Arabic language in online and offline learning is that it does not take into account the characteristic of students. Every student has different learning style that teacher must understand. So, the researchers made observation as a need analysis in Figure 1 before developing the solution of online and offline Arabic language learning problems. Based on the observation, 53 students in $5^{\text {th }}$ semester of Arabic department in Universitas Muhammadiyah Malang, Indonesia in academic year 2020-2021 have different styles in learning. 30 students have visual style in learning, 12 students have auditory style in learning, and 11 students have kinesthetic style in learning.

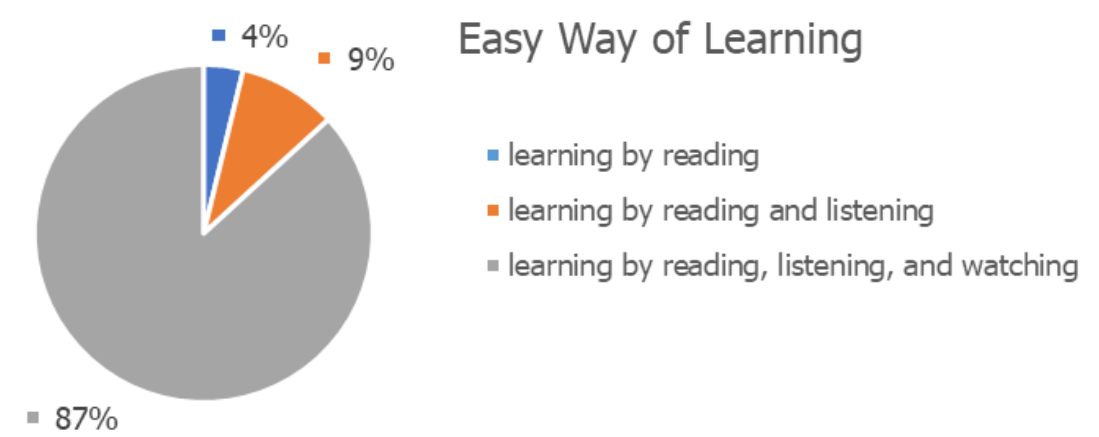

Figure 2. Students' Perception toward the Easy Way of Learning

Figure 2 was the result of survey on the students' perception toward the easy way of learning. 46 students ( $86 \%$ ) agreed that learning by reading, 
listening, and watching the visualization and explanation is the easiest way in learning. 5 students $(10 \%)$ agreed that learning is easy by reading and listening and 2 students (4\%) agreed that learning is simply by reading. The majority of students need an instructional content of Arabic learning that ease them in learning moreover in the subject ICT Pembelajaran Bahasa Arab 2 in their major of higher education in the era of Covid-19 pandemic. This need was confirmed by Edgar Dale in the cone of learning experience (Fauzi, Buhun, \& Purwadi, 2019, p. 145; Afifah, Fauzi, Anindiati, \& Nurdianto, 2020, p. 273) that the more senses used in learning, the easier it will be for students to understand the instructional content.

There are many alternative methods are available for solving the problems of Arabic language learning as a second language (L2) and/or as a foreign language. One way to overcome these problems is to create a multimedia and audio-visual instructional content in Arabic language learning. Recent methods focus on overcoming the problems by proposing different schemes for providing multimedia e-book (mE-Book) as an Arabic language instructional content in learning management system. This instructional content can be used for online and offline language learning in the era and post Covid-19 pandemic.

Previous relevant research was conducted by Martínez-Torres, Toral, and Barrero (2011, p. 1) on external variables in designing e-learning equipment. Fauzi and Anindiati (2019, p. 129) has developed digital instructional game as a content for Arabic morphology learning. Hubackova (2014, p. 353) examined elearning related to motivation in language learning. Hubackova and Semradova $(2015$, p. 51) also used e-learning for language learning by emphasizing aspects of language skills. Other research on e-learning was also conducted Hubackova \& Klimova (2013, p. 1095). The research focused on the pedagogic aspects of online language learning and issues around learning styles. Another study was also conducted by (Popovici \& Mironov, 2015) regarding student perceptions about the use of e-learning technology.

The consideration of more modern learning with technological support has led to many higher education institutions (Hanafi, Murtadho, Ikhsan, Diyana, \& Sultoni, 2019, p. 53) moreover in Covid-19 pandemic situation and post Covid19 pandemic. The pandemic is impacting all sectors and has disrupted learning in higher education. All education units are 'forced' to be ready to carry out education by adapting to existing conditions. Dong, Cao, and Li (2020, p. 1) said that online learning has been widely promoted to replace traditional face-to-face learning during the COVID-19 pandemic to maintain young children's learning and play at home. So, the development of learning must be oriented to the situation of Covid-19 and Post Covid-19 pandemic. 
Digital learning requires learners and instructors to communicate interactively by utilizing information and communication technology (Fansury, Januarty, \& Ali Wira Rahman, 2020, p. 4). In online learning, the interaction and communication patterns that are formed are online synchronous learning and online asynchronous learning. Both of these patterns occur in virtual classroom media. Although in general the patterns of interaction and communication that are formed are teacher-learner interaction, learner-learner interaction, and learner-content interaction, this pattern fully requires a learning management system or e-learning. So, $\mathrm{mE}$-Book with its characteristic for online and offline learning is breakthrough in Arabic language learning for era and post Covid-19 pandemic situation.

As far as we know, no previous research has investigated the development of multimedia e-book in Arabic language learning. No study to date has examined the effectiveness of developing mE-Book as Arabic language instructional content in Canvas Learning Management System (LMS).

The most important advantage of this research is that it can perform very well in developing instructional content of Arabic language in Canvas Learning Management System (LMS) for the era and post Covid-19 pandemic. This research had its own special characteristics and uniqueness compared to previous relevant researches. This research focused on the effectiveness of developing multimedia e-book ( $\mathrm{mE}$-Book) and designing learning content with a Canvas LMS. This research contributed to modern Arabic language learning technology because to the knowledge of the researchers, there has not been much development of Arabic learning using $\mathrm{mE}$-books as instructional content in a Canvas Learning Management System (LMS).

The aims of this research were to develop more sophisticated research for the effectiveness of $\mathrm{mE}$-Book as instructional content for Arabic language learning in Canvas LMS. With this aim in mind, in this paper researchers also presented students' perspectives for the use of $\mathrm{mE}$-Book as instructional content for Arabic language learning in Canvas LMS.

The main achievements, including contributions to the field can be summarized that $\mathrm{mE}$-Book could be implemented for online learning in Covid-19 pandemic situation because in Indonesia and many countries, schools and universities are forbidden to held face-to-face learning. The mE-Book was one of alternative solutions in digital instructional content during Covid-19 pandemic situation rather than conventional instructional content because it is accessible anywhere and anytime by students. The $\mathrm{mE}$-Book also can be said shalih li kulli zaman wa makan. It means that $\mathrm{mE}-$ Book is valid to use anytime and anywhere even in post Covid-19 pandemic situation because it is digital instructional content and can be used in online and offline learning. 


\section{METHOD}

\section{Experimental Design}

The experimental design used in this study was a nonrandomized control group pretest-posttest design (Leedy, Ormrod, \& L R Johnson, 2019). The subjects of this study involved two groups whose members were purposively selected. The second group (PBA B Class) was treated with learning using multimedia e-book (experimental) and the first group (PBA A Class) was not treated (as usual learning) namely face to face in the classroom (control). Both groups were subjected to the same measurements, namely the same pre-test and post-test, and the results were compared. The number of learning meetings, objectives, and learning materials provided to the two groups were the same. The study was conducted for half semester in odd semester of 2020-2021 academic year. The materials given were matters in the book E-Learning Pembelajaran Bahasa Arab written by Fauzi \& Anindiati (2020) from chapter 1 until chapter 7. In addition to the posttest, at the end of the study, the interviews were also conducted to find out the opinions of students in the experimental group regarding the use mE-Book which included the TAM3 components according to Venkatesh and Bala (2008). The experimental design was implemented in platform Canvas Learning Management System. The data of pretest and posttest score were taken with platform Canvas LMS by using assignment and quiz feature. The interview was also conducted in Canvas LMS because this platform was equipped with video conference feature.

\section{Participants}

The participants of this research were the fifth semester students who were taking the course of Information and Communication Technology (ICT) Pembelajaran Bahasa Arab 2 at Arabic Department, Islamic Studies Faculty, Universitas Muhammadiyah Malang, Indonesia in academic year 2020-2021. This course had two classes, namely PBA A Class and PBA B Class. PBA A Class was the control group and PBA B Class was the experimental group. The procedure before conducting the experiment, the lecturer prepared the Learning Management System (LMS), especially the preparation for using mE-Book on an Universitas Muhammadiyah Malang's LMS in address https://elmu.umm.ac.id/login/canvas. The other preparations were designing and preparing pre-tests, learning activities, posttests, and interviews. The lecturer selected two groups divided into groups treated with $\mathrm{mE}-$ Book and traditional ones (not treated with $\mathrm{mE}-$ Book). The lecturer used previous learning plans to be used in traditional classes. Meanwhile, they redesigned the learning plan for the experimental class. Before the experiment set up, mE-Book consisted of application that was used as a content of e-learning websites and was validated 
by a number of experts in instructional media, teaching material, language, and visual communication design experts. The results were declared valid and could be used for the learning.

The learning was begun in the first week of October until the end of November 2020. Pre-test activities for experimental and control group were conducted before learning began. Then, the results of the pretests were analyzed and compared. The low score of pretest group was given treatment with $\mathrm{mE}-$ Book and the higher score of pretest group was used as the control group. The learning for both groups was conducted for eight weeks with a minimum of eight face to face meetings.

Having conducted the treatment for experimental group, the students in experimental and control group were asked to complete the posttest in the last November 2020 in middle examination of the odd semester and were interviewed about their opinions on the learning process. The results of the pretest and posttest were used to analyze and compare the learning outcomes of students' ability in understanding and applying instructional content. Meanwhile, the answers of the students on the interview questions were used to analyze the perceptions of the students on the learning process carried out $\mathrm{mE}-$-Book.

The test was done by checking students' understanding on the learning materials in the $\mathrm{mE}$-Book as a post-test of half semester. This activity was an assessment of learning activities by using $\mathrm{mE}-$ Book. The assessment format has been validated by three experts in instructional media, assessment, and evaluation of learning. The results were declared valid and suitable to use in measuring the students' understanding on the learning materials in the mE-Book.

The data on students' opinions was collected with interview questions. The questions include: (1) Does learning using $\mathrm{mE}$-Book affected your understanding on the learning materials in the $\mathrm{mE}-$ Book?; (2) What are the positive aspects of using $\mathrm{mE}-$ Book in learning to increase your understanding on the learning materials in the mE-Book?; (3) Is the mE-Book more helpful for you in increasing your understanding on the learning materials in the $\mathrm{mE}-$ Book compared to learning with traditional methods?

\section{Data Analysis}

Interviews in this research were not conducted with all participants. The interviews were carried out on experimental students. Then, the results of the interviews were transcribed and coded. The analysis was undertaken with two main steps namely (1) examining in detail and carefully producing units of meaningful data and (2) classifying and categorizing in a particular theme (Alshenqeeti, 2014), according to TAM3. The way to encode used open coding methods (Lune \& Berg, 2017). The data in this research were analyzed by the 
researchers. To achieve the validity and reliability of the data, several actions were executed by the researchers at the end of this research, namely: (1) the researcher notified the main results of the analysis carried out to the participants and asked for their opinions; (2) the researcher asked for opinions from a number of experts in the same field in Arabic language teaching and learning about how accurate the results obtained. This action aimed to ensure that the data produced is accurate and impartial to anyone (Merriam, 1998).

The data acquired from the post-test were analyzed quantitatively using the descriptive and inferential statistical methods. The independent t-Test was used to measure the understanding on the learning materials in the mE-Book for the posttest of each group. Effect size was used to find the differences level of students' learning outcomes between the experimental and control groups.

\section{RESULTS \& DISCUSSION}

\section{The Effectiveness of mE-Book as Instructional Content for Arabic Language Learning in Canvas LMS}

Data of research was analyzed after data collection. Normality test was firstly conducted to find out the data normality by using Shapiro Wilk. If the significance level is higher than 0.05 ( $d>0.05)$, the data is normally distributed. Then, the data was tested using Independent Sample Test to find out the effectiveness of mE-Book for instructional content of Arabic language learning.

Test of Normality for Pretest Score was conducted in control group and experimental group. The test aimed to find out whether the data that had been obtained by researchers were normally distributed or not. The test was conducted by using Shapiro Wilk in SPSS 25.

\section{Tabel 1. Tests of Normality for Pretest Score}

\begin{tabular}{ll|r|r|r}
\hline & & \multicolumn{3}{c}{ Shapiro-Wilk } \\
\multicolumn{1}{l}{ Class } & Statistic & \multicolumn{1}{c}{ df } & \multicolumn{1}{c}{ Sig. } \\
\hline Pretest & Control Class (A) & .954 & 27 & .273 \\
\cline { 2 - 6 } Score & Experimental Class (B) & .932 & 26 & .089 \\
\hline
\end{tabular}

The normality test of pretest using Shapiro Wilk in Table 1 obtained significance score for PBA A Class (control class), it was 0.273. The degree of freedom (df) in control class was 27 data. The significance score at pre-test for PBA B Class (experimental class) was 0.089. The degree of freedom (df) in experimental class was 26 data. The score of both classes were higher than 0.05 and interpreted that the control class and the experimental class at the pretest section in subject ICT Pembelajaran Bahasa Arab 2 were normally distributed. 
Test of Normality Test for posttest was conducted in experimental class and control class. The posttest was conducted to find out whether the data that had been obtained by researchers was normally distributed or not. It was conducted by using Shapiro Wilk and SPSS 25.

Tabel 2. Tests of Normality for Posttest Score

\begin{tabular}{ll|r|r|r}
\hline & & \multicolumn{3}{|c}{ Shapiro-Wilk } \\
& Class & Statistic & \multicolumn{1}{c}{ df } & \multicolumn{1}{c}{ Sig. } \\
\cline { 2 - 6 } Posttest & Control Class (A) & .930 & 27 & .067 \\
\cline { 2 - 6 } Score & Experimental Class (B) & .870 & 26 & .056 \\
\hline
\end{tabular}

The normality test of posttest using Shapiro Wilk in Table 2 obtained significance score for PBA A Class (control class), it was 0.067 . The degree of freedom (df) in control class was 27 data. The significance score at posttest for PBA B Class (experimental class) was 0.056 . The degree of freedom (df) in experimental class was 26 data. The score of both classes were higher than 0.05 and interpreted that the control class and the experimental class at the posttest section in subject ICT Pembelajaran Bahasa Arab 2 were normally distributed.

Independent sample test was conducted after getting know that the data of posttest for both experimental class and control class were normally distributed. The independent sample test was conducted each data in experimental and control class was not paired and less than 30 students. T-test was used to determine the effectiveness level of using $\mathrm{mE}$-Book by the assistance of SPSS 25 with significance level of 0.05 . The formulation of hypothesis was 1 ) $\mathrm{H}_{0}$ : mE-Book as Instructional Content for Arabic Language Learning in Canvas LMS was not effective and 2) $\mathrm{H}_{1}$ : mE-Book as Instructional Content for Arabic Language Learning in Canvas LMS was effective. T-test was used to test whether there was an average difference between the two free samples assuming the data whether normally distributed with the provisions that if the probability was higher than 0.05 then the hypothesis $\left(\mathrm{H}_{0}\right)$ is accepted but if the probability was less than 0.05 then the hypothesis $\left(\mathrm{H}_{1}\right)$ is accepted.

Table 3. Independent Samples Test

\begin{tabular}{|c|c|c|c|c|c|c|c|c|c|c|}
\hline & & \multicolumn{2}{|c|}{$\begin{array}{c}\text { Levene's Test } \\
\text { for Equality of } \\
\text { Variances }\end{array}$} & \multicolumn{7}{|c|}{ t-test for Equality of Means } \\
\hline & & & & & & $\begin{array}{l}\text { Sig. } \\
(2-\end{array}$ & $\begin{array}{l}\text { Mean } \\
\text { Differ- }\end{array}$ & $\begin{array}{l}\text { Std. } \\
\text { Error } \\
\text { Differ- }\end{array}$ & $\begin{array}{r}95 \% \mathrm{C} \\
\text { Interv } \\
\text { Diffe }\end{array}$ & $\begin{array}{l}\text { fidence } \\
\text { of the } \\
\text { ence }\end{array}$ \\
\hline & & $\mathrm{F}$ & Sig. & $\mathrm{t}$ & df & tailed) & ence & ence & Lower & Upper \\
\hline \multirow[t]{2}{*}{$\begin{array}{l}\text { Posttest } \\
\text { Score }\end{array}$} & $\begin{array}{l}\text { Equal variances } \\
\text { assumed }\end{array}$ & .956 & .333 & -2.711 & 51 & .009 & -6.380 & 1.984 & -9.364 & -1.397 \\
\hline & $\begin{array}{l}\text { Equal variances } \\
\text { not assumed }\end{array}$ & & & -2.726 & 48.383 & .009 & -6.380 & 1.974 & -9.349 & -1.412 \\
\hline
\end{tabular}


Table 3 explained the posttest score of the control class and experimental class after using mE-Book. Levene's Test for equality of variances was $0.956>$ 0.05. It meant there was no difference in variant of the data on posttest score between experimental and control class. The data is homogenic and equal because Sig: $p>0.05$. From Table 3, the data interpretation was taken from data equal variances assumed because the data was homogenic and equal. The result of t-test for equality of means in Table 3 showed that the score of sig. (2-tailed) was 0,009 . The score was less than $0.05(0.009<0.05)$. It meant that $\mathrm{H}_{0}$ was rejected and $\mathrm{H}_{1}$ was accepted. It coulde be interpreted that here was difference learning outcomes between control class and experimental class after using $\mathrm{mE}$ Book as Instructional Content for Arabic Language Learning in Canvas LMS.

Mean difference of posttest score in Table 3 was -6.380 . This score showed the difference score between the experimental and control class. Then, the Effect size test was used to find out the significance level of effectiveness of mE-Book as Instructional Content for Arabic Language Learning in Canvas LMS toward students' learning outcomes. The calculation of posttest score siginificance for students' posttest score used effect size as it was shown in Table 4. The calculation of effect size in this research was compared using Cohen's $d$, Glass's delta, and Hedges' $g$.

Table 4. Calculator of Effect Size

\begin{tabular}{cccccc}
\hline No & Formula of Effect Size & $\mathbf{M}_{\mathbf{2}}$ & $\mathbf{M}_{\mathbf{1}}$ & $\mathbf{S D}_{\text {pooled }}$ & Result \\
\hline $\mathbf{1}$ & Cohen's $d$ & 85.27 & 78.89 & 7.202551 & 0.885797 \\
\hline $\mathbf{2}$ & Glass's de/ta & 85.27 & 78.89 & 8.116 & 0.786102 \\
\hline $\mathbf{3}$ & Hedges' $\boldsymbol{g}$ & 85.27 & 78.89 & 7.221572 & 0.883464 \\
\hline
\end{tabular}

Table 4 explained the calculation of effect size by using 3 different formulas. Cohen's $d$ is the appropriate effect size measure if two groups have similar standard deviations and are of the same size. Glass's delta, which uses only the standard deviation of the control group, is an alternative measure if each group has a different standard deviation. Hedges' $g$, which provides a measure of effect size weighted according to the relative size of each sample, is an alternative where there are different sample sizes. The Mean $\left(M_{2}\right)$ of posttest score of experimental group was 85.27 with 26 sample size. The Mean $\left(M_{1}\right)$ of posttest score of control group was 85.27 with 27 sample size. The data of this research had different sample size. So, the calculation of Hedge's $g$ was used to determine the significance level of the data. The result of Hedge's $g$ calculation was 0.883464 and it was rounded to 0.88 . 
Table 5. Category of Effect Size

\begin{tabular}{ccc} 
No & Criteria of Effect Size & Category \\
\hline $\mathbf{1}$ & $\mathrm{d}<0,2$ & Small Effect \\
\hline $\mathbf{2}$ & $0,2<\mathrm{d}<0,8$ & Medium Effect \\
\hline $\mathbf{3}$ & $\mathrm{d}>0,8$ & Large Effect
\end{tabular}

Table 5 described the category and criteria of effect size, the higher the score of Effect Size (ES), the higher effectiveness of mE-Book as Instructional Content for Arabic Language Learning in Canvas LMS. If the range score of effect size criteria is less than 0.2 , the category is small. If the range score of effect size criteria is between 0.2 until 0.8 , the category is medium. If the range score of effect size criteria is higher than 0.8 , the category is large. Based on criteria of effect size in Table 5, the result of calculation, by using Hedge's $g$ calculation which is 0.88 , could be concluded that the effectiveness level of was included in the category of large effect.

The results of quantitative data showed that mE-Book as Instructional Content for Arabic Language Learning in Canvas LMS was effective and had large effect on students' learning outcomes even the activity of teaching and learning was online because of Covid-19 pandemic and needed e-learning as a media. So, the selection of e-learning is very important because the students have different charateristics and learning styles.

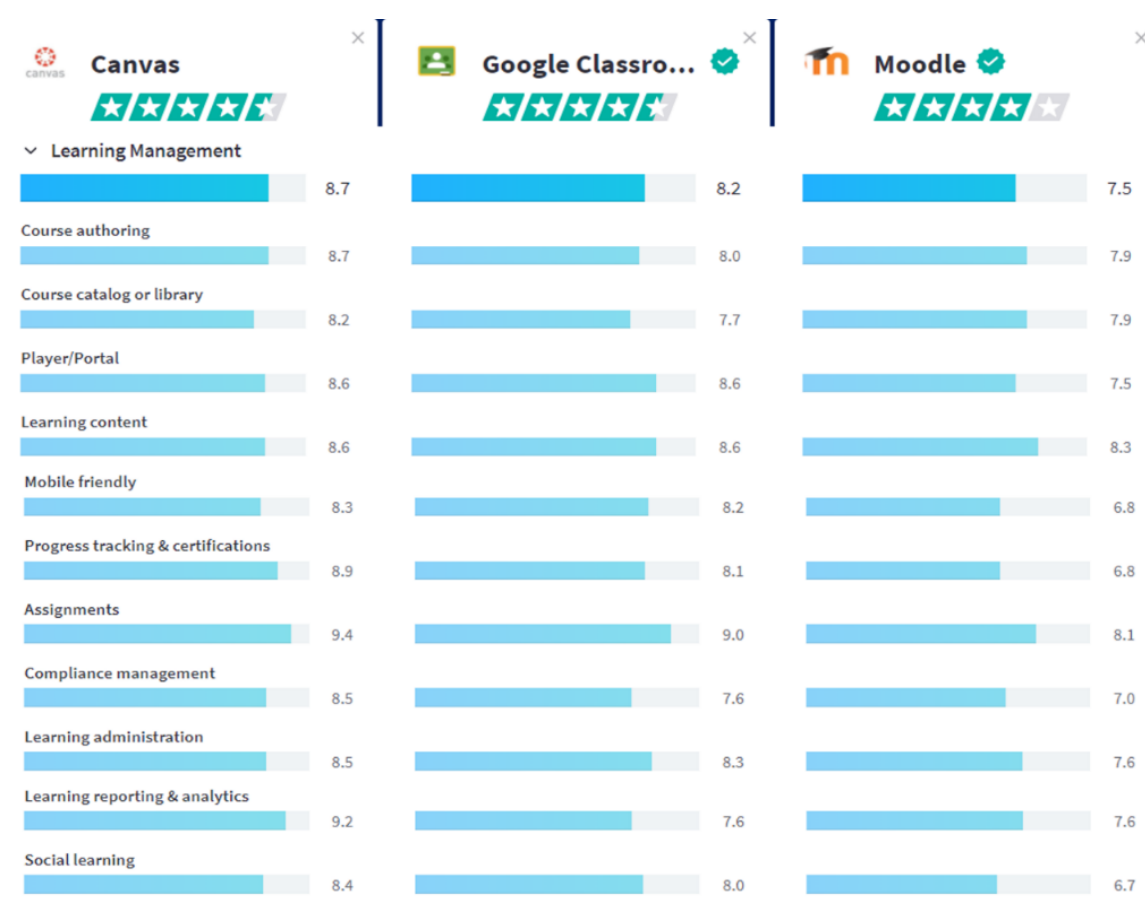

Figure 3. Feature Rating Comparison

(source: https: //www.trustradius.com/compare-products/canvas-vsgoogle-classroom-vs-moodle) 
Figure 3 described about feature rating comparison among Canvas, Google Classroom, and Moodle. Canvas has more superior features compared to other e-learning that is widely used. The advantages can be seen from the difference in ratings by users in the field of learning and education which are taken from the website https://www.trustradius.com/compare-products/canvas-vs-googleclassroom-vs-moodle (www.trustradius.com, 2020). As learning management system, Canvas is the best e-learning in learning management, course authoring, course catalog or library, mobile friendly, progress tracking and certifications, assignments, compliance management, learning administration, learning reporting and analytics, and social learning. For the features of player/portal and learning content, Canvas is as good as Google Classroom.

The basis for selecting the Canvas LMS in this study was because the complete features and ease of use as described in Figure 3. Several studies specifically discussed the use of Canvas LMS because of its features. There were many researches in journal articles and dissertation on the use of Canvas LMS (Baldwin \& Ching, 2019, p. 269; Falcone, 2018, p. 1; Fathema \& Akanda, 2020, p. 113; Mpungose \& Khoza, 2020, p.1; Rojas \& Jaimes, 2020, p. 1; Song \& Luan, 2020, p. 1; Towne, 2018, p. 1).

The implementation of mE-Book as Instructional Content for Arabic Language Learning in Canvas LMS is important because the mE-Book was effective with large effect size. It was also used in E-Learning Canvas that is widely used in USA and in many countries in the world. Marachi and Quill (2020, p. 418) said that The Canvas LMS is used in thousands of universities across the United States and internationally, with a strong and growing presence in K-12 and higher education markets. Endozo, Oluyinka, and Daenos (2019, p. 91) said that Canvas is the world's most reliable LMS. Paynter and Barnes (2019, p. 1315) said that Canvas is innovative and completely different from other learningmanagement systems. Canvas has rapidly gained market share and is currently used at more than 4,000 institutions worldwide.

\section{Students' Perspectives for the Use of mE-Book as Instructional Content for Arabic Language Learning in Canvas LMS.}

A system change in learning activities from face-to-face meeting (offline) to the online learning in Covid-19 Pandemic that occur suddenly include various problems ranging from students, teaching staff, administrative staff who are not ready for online learning, and unequal support facilities in various regions in Indonesia. This is a challenge for the Indonesian people in implementing elearning. Competence attainment in the learning process is hampered. Cooperation, roles, and support from various parties including the government, education providers, students and parents are needed to unravel the tangled 
threads of online learning problems in Indonesia. The instructional content is one of the important things in online teaching and learning. mE-Book is one of the solution for the useful instructional content.

The researches conducted interviews to the students who were taking the course of Information and Communication Technology (ICT) Pembelajaran Bahasa Arab 2 at Arabic Department, Islamic Studies Faculty, Universitas Muhammadiyah Malang, Indonesia in academic year 2020-2021. The students was treated by using mE-Book in teaching and learning. Then, The researchers found that generally the students felt that the use of mE-Book had helped them in learning activities in Canvas LMS rather than another class that were not treated. The students expressed the satisfaction with the implementation of $\mathrm{mE}$ Book in Arabic learning. The average responses of students were categorized into perceived usefulness in online and offline learning because $\mathrm{mE}$-Book can be used as self-learning access online and offine.

Student 1: "In my opinion, the use of $\mathrm{mE}-$ Book in blended learning is effective, this is because the learning system is different from the previous one (offline). When learning is done online, it is likely that the understanding of the material tends to decrease this is due to several factors such as a lack of 2-way interaction. But by using mE-Book, I can learn the instructional content repeatedly by my self because there is audio and video explanation in the book".

Student 2: "It ( $\mathrm{mE}-$-Book) is very helpful because besides reading, students are also given a video explanation of the material in the nuances of a book".

Student 3: "In my opinion, it (mE-Book) is effective, because this is interesting for me who is just learning by using it for the first time".

Student 4: "In my opinion, the use of me books for blended learning is quite good and interesting, because in $\mathrm{mE}-$-Book we can use several types of multimedia such as audio, video and others, which can help students understand the material easily".

Student 5: "In my opinion, mE-Book in learning is quite good as a learning medium, in which it gives a different impression than just reading a book".

Student 6: "In my opinion, it ( $\mathrm{mE}-$-Book) is extraordinary, besides being able to facilitate my understanding in learning, $\mathrm{mE}$-Book also has a lot of qualities in it that can be learned online or offline. At the same time, it can generate more interest in the mE-Book."

Student 7: "I can use mE-Book offline for self-learning. So, sometimes it can replaced the role of lecturer in learning".

The interview data is the result of interviews with students who used the mE-Book in learning the course ICT Pembelajaran Bahasa Arab 2. The mE-Book was developed from the printed version of the E-Learning Pembelajaran Bahasa Arab book. 


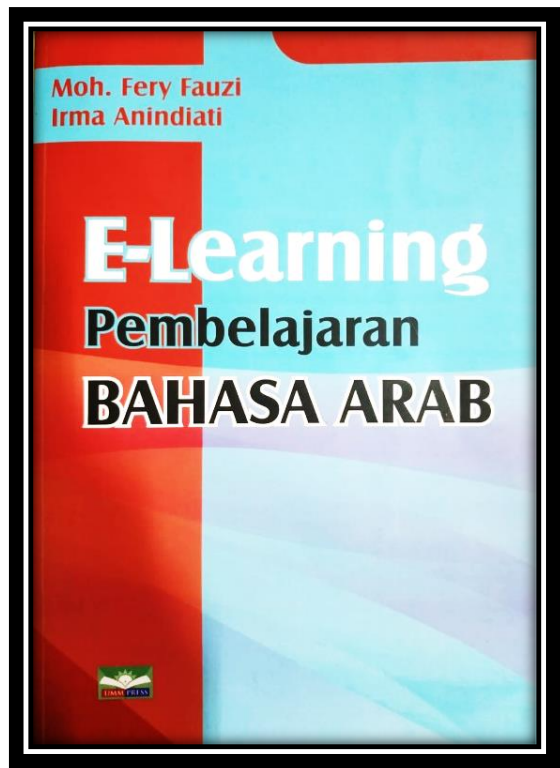

Figure 4. mE-Book entitled "E-Learning Pembelajaran Bahasa Arab"

Figure 4 described the printed version book of E-Learning Pembelajaran Bahasa Arab. From this book, the mE-Book was developed in the shape of multimedia electronic book. The mE-Book was implemented in teaching and learning in Canvas LMS.

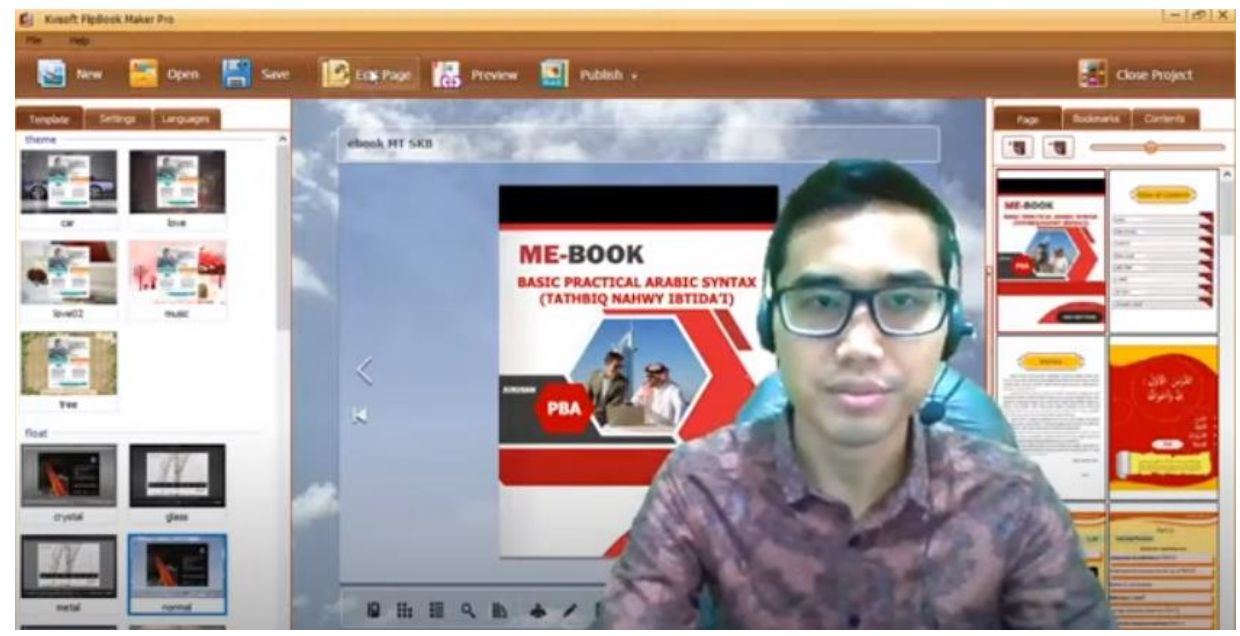

Figure 5. mE-Book in Canvas LMS

Figure 5 described the multimedia electronic book. This book was used for treatment in PBA B Class in teaching and learning process in Canvas LMS. The students' perspectives mostly agreed that mE-Book can help them in understanding the instructional matters online and offline. They learn by themselves repeatedly on the learning materials. 


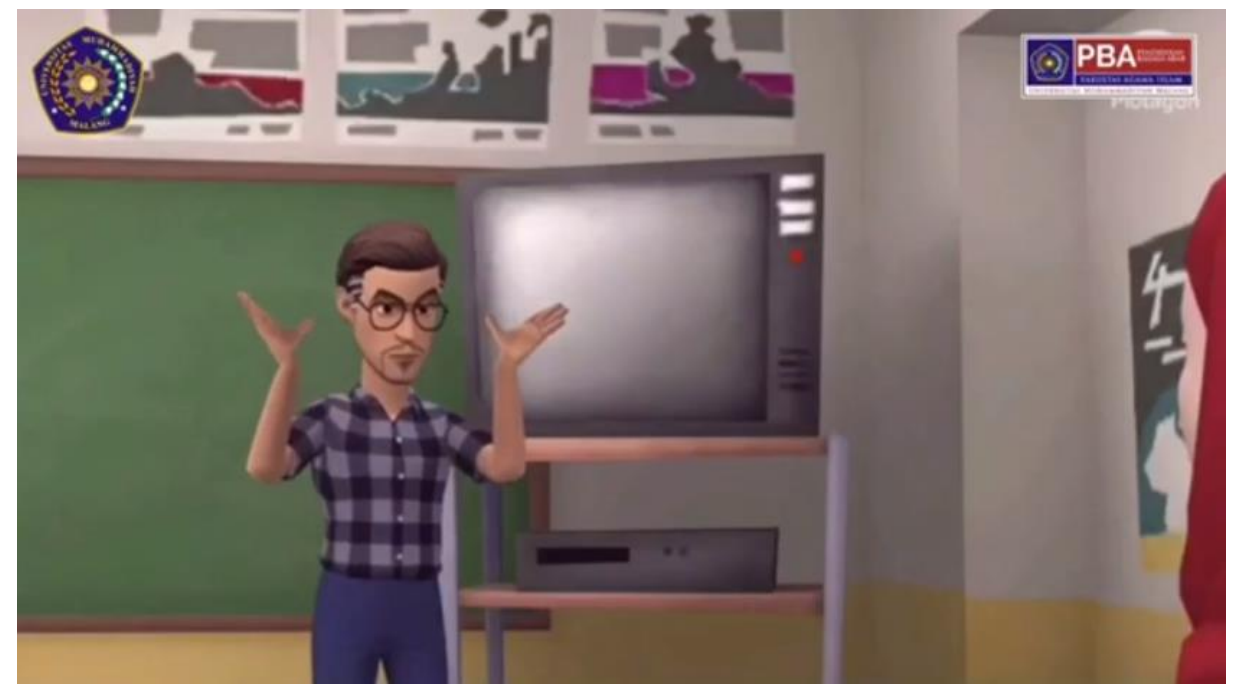

Figure 6. Arabic Language Animated Video in mE-Book

Figure 6 described the instructional content in mE-Book. It contains Arabic language animated video. Students can access the video in mE-Book. This instructional content can be used for blended learning.

Teaching Arabic language needs an innovation moreover in Covid-19 Pandemic situation. Annamalai $(2016$, p. 322) said that the integration of multimedia features into e-books, such as text, sound, and videos in the classroom is becoming a potential teaching and learning tool in language learning. Alwan (2018, p. 26) said that multimedia electronic book could be developed because it can help the delivery of learning material easier, more attractive for self-learning, and have no boundaries in space and time. (Hanafi, Murtadho, Ikhsan, \& Diyana, 2020) said that the technology of multimedia is believed as being able to help students and multimedia can provide conducive atmosphere and visualize information dynamically and interestingly. Fauzi, Salahuddin, and Mauludiyah (2020, p. 152) said that one of the factors that causes the unsuccessfulness of learning Arabic is the media that does not support students to learn Arabic.

Multimedia provides opportunities for teachers and educators to develop and increase learning techniques with maximum results. In order to achieve learning goals, teachers and educators need to understand useful learning techniques in the teaching and learning process. Mulyadi, Atmazaki, and Syahrul (2019, p. 292) said that learning techniques are used to implement a method specifically, for example the use of learning resources-based multimedia. Using multimedia in learning becomes an obligation and it is in line with the changes that occur in various fields of human life. Likewise, for students in higher education, with multimedia, they are expected to be easier to determine with what and how students can absorb information quickly and efficiently. Sources 
of information are no longer focused on text from books but are wider than that.

The use of mE-Book needs to be implemented in an appropriate way. Problems around learning are very diverse and need to be resolved with the right solutions, especially online learning problems in Arabic language teaching during the Covid-19 pandemic. If the mE-Book that has been researched and resulted great effectiveness according to this effect size is applied with the right e-learning media, the learning will be more effective. In addition, the use of appropriate communication and interaction methods and patterns in accordance with student characteristics is also very important. Riyanta et al., $(2020$, p. 85$)$ said that learning activities are very complex. The use of Information and Communication Technology in online learning practices should not ignore pedagogy, psychology, and other aspects that affect the success of the teaching and learning process.

\section{CONCLUSIONS}

This research showed that the mE-Book as instructional content for Arabic language learning in Canvas LMS is effective. This effect, based on Effect Size, was categorized large effect. It was also more effective than use printed book or only e-book because mE-Book can visualize the learning materials. From students' point of view, the use of mE-Book as instructional content for Arabic language learning in Canvas LMS is interesting for online and offline learning. This assumption showed that students could accept mE-Book in learning activity in Canvas LMS. Future research can be conducted on the appropriate method of teaching Arabic language using $\mathrm{mE}$-Book because there were many problems in technology, teaching materials, and pedagogy faced by teachers and students for online learning during era and post Covid-19 Pandemic.

\section{ACKNOWLEDGMENT}

We would like to thank all people who helped this research until it was published in the journal. Thank you to the students in Arabic Department, Islamic Studies Faculty, Universitas of Muhammadiyah Malang for their cooperative attitude in conducting research.

\section{BIBILIOGRAPHY}

Afifah, N., Fauzi, M. F., Anindiati, I., \& Nurdianto, T. (2020). The Implementation of Mimicry Memorization Method for Novice Students in Learning Arabic Mufradat. Jurnal Al Bayan: Jurnal Jurusan Pendidikan 
Bahasa Arab, 12(2), 263-280.

https://doi.org/10.24042/albayan.v12i2.5953

Alshenqeeti, H. (2014). Interviewing as a Data Collection Method: A Critical

Review. English Linguistics Research, 3(1).

https://doi.org/10.5430/elr.v3n1p39

Alwan, M. (2018). Pengembangan Multimedia E-Book 3D Berbasis Mobile Learning Untuk Mata Pelajaran Geografi SMA Guna Mendukung Pembelajaran Jarak Jauh. At-Tadbir: Jurnal Manajemen Pendidikan Islam, 2(1), 26-40. https://doi.org/10.3454/at-tadbir.v1i2.3009

Annamalai, S. (2016). Designing motivating mE-book for polytechnic language classroom using ARCS model. The European Proceedings of Social \& Behavioral Sciences XIV, 320-326. https://doi.org/10.15405/epsbs.2016.08.45

Baldwin, S. J., \& Ching, Y.-H. (2019). Online course design: A review of the Canvas course evaluation checklist. International Review of Research in Open and Distributed Learning, 20(3), 269-282. https://doi.org/10.19173/irrodl.v20i3.4283

Brudermann, C. A. (2015). Computer-Mediated Online Language Learning Programmes vs. Tailor-Made Teaching Practices at University Level: A Foul Relationship or a Perfect Match? Open Learning, 30(3), 267-281. https://doi.org/10.1080/02680513.2015.1100069

Chang, M. M. (2007). Enhancing web-based language learning through selfmonitoring. Journal of Computer Assisted Learning, 23(3), 187-196. https://doi.org/10.1111/j.1365-2729.2006.00203.x

De Paepe, L., Zhu, C., \& Depryck, K. (2018). Online Dutch L2 learning in Adult Education: Educators' and Providers' Viewpoints on Needs, Advantages and Disadvantages. Open Learning, 33(1), 18-33. https://doi.org/10.1080/02680513.2017.1414586

Dong, C., Cao, S., \& Li, H. (2020). Young children's online learning during COVID-19 pandemic: Chinese parents' beliefs and attitudes. Children and Youth Services Review, 118, 105440. https://doi.org/10.1016/j.childyouth.2020.105440

Endozo, A. N., Oluyinka, S., \& Daenos, R. G. (2019). Teachers' Experiences towards Usage of Learning Management System: CANVAS. Proceedings of the 2019 11th International Conference on Education Technology and Computers, 91-95. https://doi.org/https://doi.org/10.1145/3369255.3369257

Falcone, K. (2018). A Case Study of Faculty Experience and Preference of Using Blackboard and Canvas LMS (pp. 1-198). pp. 1-198. University of Phoenix.

Fansury, A. H., Januarty, R., \& Ali Wira Rahman, S. (2020). Digital content for 
millennial generations: Teaching the English foreign language learner on COVID-19 pandemic. Journal of Southwest Jiaotong University, 55(3). https://doi.org/10.35741/issn.0258-2724.55.3.40

Fathema, N., \& Akanda, M. H. (2020). Effects of instructors' academic disciplines and prior experience with learning management systems: A study about the use of Canvas. Australasian Journal of Educational Technology, 36(4), 113-125. https://doi.org/10.14742/AJET.5660

Fauzi, M. F., Fatoni, A., \& Anindiati, I. (2020). Pelatihan Peningkatan Kualitas Evaluasi Pembelajaran Bahasa Arab Berbasis Information Dan Communication Technology (ICT). Jurnal Terapan Abdimas, 5(2), 173-181. https://doi.org/10.25273/jta.v5i2.5620

Fauzi, M. F., \& Anindiati, I. (2019). Tathwir al-Lughaz al-Raqmy li Madah alTathbiq Al-Sharfy 1 'ala al-Hatif al-Mahmul ka al-Tadribat al-Idhafiyyah Kharij al-Fashl al-Dirasy. Buletin Al-Turas, 25(1), 129-139. https://doi.org/10.15408/bat.v25i1.11506

Fauzi, M. F., \& Anindiati, I. (2020). E-Learning Pembelajaran Bahasa Arab. Malang: UMM Press.

Fauzi, M. F., Buhun, M. F., \& Purwadi, A. (2019). The Influence of Teams Games Tournament (TGT) toward Students' Interest in Arabic Language Learning. Izdihar: Journal of Arabic Language Teaching, Linguistics, and Literature, 2(2), 135-148. https://doi.org/10.22219/jiz.v2i2.9986

Fauzi, M. F., Salahuddin, H., \& Mauludiyah, L. (2020). The Effectiveness of Arabic Video Animation in Improving the Mastery of Arabic Vocabulary. International Journal of Arabic Language Teaching, 2(2), 149-161. https://doi.org/10.32332/ijalt.v2i02.2499

Fitriyah, T., \& Fauzi, M. F. (2020). Improving Quality of Arabic Translation Course through Jigsaw Cooperative Learning. Izdihar: Journal of Arabic Language Teaching, Linguistics, and Literature, 3(1). https://doi.org/10.22219/jiz.v3i1.11033

Foster, I. (2019). The Future of Language Learning. Language, Culture and Curriculum, 32(3), 261-269. https://doi.org/10.1080/07908318.2019.1661154

Furqon, M. R., \& Fauzi, M. F. (2019). The Values of Educational Character in the Arabic Temples of Qasidah Burdah by Imam Bushiri. Izdihar: Journal of Arabic Language Teaching, Linguistics, and Literature, 2(1), 67-76. https://doi.org/10.22219/jiz.v2i1.8327

Hanafi, Y., Murtadho, N., Ikhsan, M. A., \& Diyana, T. N. (2020). Reinforcing Public University Student's Worship Education by Developing and Implementing Mobile-Learning Management System in the ADDIE Instructional Design Model. International Journal of Interactive Mobile 
Technologies (IJIM), 14(02), 215-241.

https://doi.org/10.3991/ijim.v14i02.11380

Hanafi, Y., Murtadho, N., Ikhsan, M. A., Diyana, T. N., \& Sultoni, A. (2019).

Student's and Instructor's Perception toward the Effectiveness of E-BBQ Enhances Al-Qur'an Reading Ability. International Journal of Instruction, 12(3), 51-68. https://doi.org/10.29333/iji.2019.1234a

Hubackova, S. (2014). Motivation in eLearning Motivation in language courses.

Procedia-Social and Behavioral Sciences, 122, 353-356.

https://doi.org/10.1016/j.sbspro.2014.01.1353

Hubackova, S., \& Klimova, B. F. (2013). Pedagogical aspects of eLearning. Language on-line course and issues of learning styles. Procedia-Social and Behavioral Sciences, 93, 1095-1098.

https://doi.org/10.1016/j.sbspro.2013.09.337

Hubackova, S., \& Semradova, I. (2015). Language skills as eLearning course contents. Procedia-Social and Behavioral Sciences, 182, 51-54. https://doi.org/10.1016/j.sbspro.2015.04.736

Leedy, P. D., Ormrod, J. E., \& L R Johnson. (2019). Practical Research: Planning and Design (Twelfth edition) (12th ed.). NY: Pearson.

Lune, H., \& Berg, B. L. (2017). Qualitative Research Methods for the Social Sciences (Ninth Edition). Boston: Pearson.

Marachi, R., \& Quill, L. (2020). The case of Canvas: Longitudinal datafication through learning management systems. Teaching in Higher Education, 25(4), 418-434. https://doi.org/10.1080/13562517.2020.1739641

Martínez-Torres, M. del R., Toral, S. L., \& Barrero, F. (2011). Identification of the design variables of eLearning tools. Interacting with Computers, 23(3), 279-288. https://doi.org/10.1016/j.intcom.2011.04.004

Merriam, S. B. (1998). Qualitative Research and Case Study Applications in Education. Revised and Expanded from" Case Study Research in Education.". (2nd Editio). San Fransisco: Jossey-Bass Publishers.

Mpungose, C. B., \& Khoza, S. B. (2020). Postgraduate Students' Experiences on the Use of Moodle and Canvas Learning Management System. Technology, Knowledge and Learning, 1-16. https://doi.org/10.1007/s10758-02009475-1

Mulyadi, M., Atmazaki, A., \& Syahrul, R. (2019). The Development of Interactive Multimedia E-Module on Indonesia Language Course. 1st International Conference on Innovation in Education (ICoIE 2018), 291295. https://doi.org/10.2991/icoie-18.2019.65

Paynter, K., \& Barnes, J. (2019). Moving from Blackboard to Canvas: What the Research Says, Plus Two Professors' Experiences. E-Learn: World 
Conference on E-Learning in Corporate, Government, Healthcare, and Higher Education, 1314-1320. https://www.learntechlib.org/p/211220/

Popovici, A., \& Mironov, C. (2015). Students' perception on using eLearning technologies. Procedia-Social and Behavioral Sciences, 180, 1514-1519. https://doi.org/10.1016/j.sbspro.2015.02.300

Rienties, B., Lewis, T., McFarlane, R., Nguyen, Q., \& Toetenel, L. (2018). Analytics in Online and Offline Language Learning Environments: The Role of Learning Design to Understand Student Online Engagement. Computer Assisted Language Learning, 31(3), 273-293. https://doi.org/10.1080/09588221.2017.1401548

Riyanta, B., Hamid, E. S., Prasetyo, H., Hamid, H., Khair, H., Ahmad, J., ... Siswanto, W. A. (2020). Pembelajaran Daring PTMA di Masa Pandemi Covid-19 (Edisi Pertama; E. S. Hamid \& M. Khalil, Eds.). Yogyakarta: Majelis Diktilitbang PP Muhammadiyah.

Rojas, L. F. M., \& Jaimes, N. M. (2020). Canvas LMS and Collaborative work as a learning methodology in virtual environments. 2020 15th Iberian Conference on Information Systems and Technologies (CISTI), 1-6. IEEE.

Rusman, R., Deni Kurniawan, \& Riyana, C. (2013). Pembelajaran Berbasis Teknologi Informasi dan Kamunikasi: Mengembangkan Profesionalitas Guru. Jakarta: Rajawali Press.

Song, Y. N., \& Luan, Z. Q. (2020). Function Design Optimization of Learning Management System (LMS) Based on Student Perspective-Case Study of Canvas Application University of Colorado Denver. Journal of Physics: Conference Series, 1621(1), 1-5. IOP Publishing.

Towne, T. (2018). Exploring the Phenomenon of Secondary Teachers Integrating the LMS Canvas in a Blended-Learning Course. Liberty University.

Venkatesh, V., \& Bala, H. (2008). Technology Acceptance Model 3 and a Research Agenda on Interventions. Decision Sciences, 39(2), 273-315. https://doi.org/10.1111/j.1540-5915.2008.00192.x

www.trustradius.com. (2020). Feature Rating Comparison Canvas, Google Classroom, and Moodle. Date accessed 26/12/2020.

Zhang, R., \& Zou, D. (2020). Types, Purposes, and Effectiveness of State-ofthe-art Technologies for Second and Foreign Language Learning. Computer Assisted Language Learning, O(0), 1-47. https://doi.org/10.1080/09588221.2020.1744666 